\title{
The Influence of E-Trust, User's Experiences, and Brand Equity on Gen Z Female Customers E-Loyalty Towards Imported Cosmetics Brands Through Customers E-Satisfaction
}

\section{Retno Tri Handayani ${ }^{1 *}$, Annie Susanto ${ }^{2}$}

1,2 Universitas Kristen Satya Wacana

\section{A R T I C L E I N F O \\ Article history: \\ Received 12 February 2020 \\ Received in revised form \\ 29 March 2020 \\ Accepted 18 April 2020 \\ Available online 30 May \\ 2020}

Keywords:

E-Trust, User's Experiences, Brand Equity, E-Loyalty,

Customers' E-Satisfaction

\begin{abstract}
A B S T R A C. T
In this era, globalization as well as the emergence of technology has led to online shopping trend especially among Generation Z who could not be separated from technology. This trend has also created an open market for countries to distribute their products. In any online businesses, e-loyalty and e-trust have been some of the important issues that might create obstacles on having long-term profits because lack of/low customer loyalty. Therefore, this study aimed at analysing and finding the influence of E-Trust, User's Experiences, and Brand Equity on Gen Z female Customers' E-Loyalty towards imported cosmetics brands through Customers' E-Satisfaction. The population of this study was Gen Z female community in Indonesia with the samples of 200 respondents taken by non-probability sampling technique. The qualitative method used in this study was supported by the data collection through questionnaires spread in three areas; Central Java, West Java and outside Java. The data analysis method used was multiple linear regression analysis. The result showed that E-Trust in this study did not have a positive effect on Customers' E-satisfaction while User's Experiences and Brand Equity had positive effects on Customers' E-Satisfaction. Other than that, Customers' E-Satisfactions did not mediate the influence of E-Trust, User's Experiences and Brand Equity on Customers' Loyalty.
\end{abstract}

\footnotetext{
* Corresponding author.

E-mail addresses: 212016515@student.uksw.edu (Retno Tri Handayani)
} 


\section{Introduction}

In this globalization era, there is an important issue in business called e-loyalty. This issue occurs in online businesses, as customers can easily access several different online stores to compare products before purchasing ( $\mathrm{Lu}, \mathrm{Chang}, \& \mathrm{Yu}, 2013$ ). Therefore, customers do not only choose from one specific online store to purchase the desired items, but they can both easily and freely buy goods from any other online stores. The difficulty in creating profits for a long-term online business is caused by lack/low customer loyalty in online shopping (Deng, Lu, Wei, \& Zhang, 2010). Another issue of online shopping is etrust. When trust is formed for a certain online store, customers will feel sure to purchase and return to repurchase the goods in that particular online store.

Online shopping happens because of the development of technology. Generation $\mathrm{Z}$ is a digital native because this generation cannot be separated from technologies including the internet (Budac, 2014). Internet technology makes it easy for customers to search online stores to make purchases on products, including varieties of international cosmetics products (Debora, 2016). The situation is approximately the same in Indonesia with $48 \%$ of Indonesian customers prefer to buy foreign brands cosmetics rather than the local ones (katadata.co.id, 2016), with Korean brand as the most wanted (tempo.co, 2018). The interest level of online shopping through the internet among Gen $\mathrm{Z}$ is high and their experience affects the loyalty to visit the same online store (Budac, 2014). However, online purchases can cause customers' concern due to the uncertainties (Chou et al., 2015).

The past study by Nam, Ekinci, \& Whyatt, (2011) explained that customers tend to seek products information through the internet. Later on, the information may determine the value of the products that might be perceived differently in the customers' eyes. Therefore, a product can have a very strong position in customers' minds and create the brand equity. The stronger the brand equity of a product, the more it will attract customers and lead to customers' e-loyalty. Based on that, this study focuses on (1) How does e-trust affect customers' e-satisfaction to Korean cosmetics brands? (2) How do users' experiences affect customer e-satisfaction to Korean cosmetics brands? (3) How does brand equity affect customer esatisfaction to Korean cosmetics brands? (4) Does customer e-satisfaction mediate the influence of e-trust, user's experiences, and brand equity on customer' e-loyalty?.

\section{Methods}

This study used quantitative method with Gen $\mathrm{Z}$ female community in Indonesia as the population. Sugiyono (2012) suggested that the sample measurement in a study must be between 30 and 500 . Therefore, to obtain accurate data, this study took 200 samples. Non-probability sampling requirements and criteria of this study are: (1) Female; born between the years of 1995 and 2010 (19-24 years old in 2019), (2) Have purchased Korean cosmetics brands online at least 2 times in the last 2 months, (3) Have purchased one or several of the following Korean cosmetics brands (Laneige, Etude House, Sulwhasoo, The Face Shop, The Saem, Moonshot, Nature Republic, Missha, Tony Moly, Skinfood, and Innisfree) online. The data was collected through questionnaire using Google Form. The questionnaire used five-point Likert Scale with 5 as the highest point (completely agree) to measure respondents' attitudes toward certain statements. The data was then analysed using Multiple Linear Regression from the SPSS statistical software for hypothesis testings.

\section{Result And Discussion}

\section{Respondents Characteristics}

All respondents are women with 55.5\% of them aged between 19-21 years old and the rest of $44.5 \%$ are between 22-24 years old. The respondents living in area 1 (Central Java) are 172 people while those from area 2 (West Java) are 14 people and area 3 (outside of Java) are 14 people. For the total amount of expenditure per month, half of respondents spend > IDR 1,000,000, the other $46.5 \%$ respondents spend IDR 500,000 - IDR 1,000,000 and the rest spend < IDR 500,000. For the average amount of total cosmetic expenditure per month, the majority of the respondents spend between IDR 200,000 - IDR 400,000 while $34 \%$ respondents spend > IDR 400.000 and the rest spend < IDR 200,000. 
Table 1 Respondent Characteristics

\begin{tabular}{lll}
\hline Characteristic & Number of People & Percentage \\
\hline Age & & \\
1.19-21 years old & 111 & $55.5 \%$ \\
2.22-24 years old & 89 & $44.5 \%$ \\
3. 25 years old & 0 & $0 \%$ \\
Gender & 0 & $0 \%$ \\
$\quad$ 1. Male & 200 & $100 \%$ \\
2. Female & 172 & $0.86 \%$ \\
Residence & 14 & $0.07 \%$ \\
1. Area 1 (Central Java) & 14 & $0.07 \%$ \\
2. Area 2 (West Java) & & \\
3. Area 3 (outside Java) & 6 & $3 \%$ \\
Total amount of expenditure per month & 93 & $50.5 \%$ \\
1.< IDR 500.000 & 101 & \\
2. IDR 500.000 - IDR 1.000.000 & & \\
3. > IDR 1.000.000 & & $5 \%$ \\
The average amount of total cosmetic expenditure per month & 16 & $34 \%$ \\
1.< IDR 200.000 & 116 & Source: Primary Data (2020) \\
2. IDR 200.000 - IDR 400.000 & 68 &
\end{tabular}

Descriptive Statistics on E-Trust, User's Experiences, Brand Equity, Customer E-Satisfaction, and Customer E-Loyalty

Table 2 E-Trust

\begin{tabular}{llllllll}
\hline Variable & Statement & N & \multicolumn{3}{c}{ Percentage (\%) } \\
\hline E-Trust & $\begin{array}{l}\text { I feel that online stores will not convey my } \\
\text { personal data /information to other parties } \\
\text { without permission. }\end{array}$ & 200 & 23.5 & 51 & 23 & 2.5 & 0 \\
& $\begin{array}{l}\text { I believe that online stores apply security } \\
\text { methods to protect the online buyers. }\end{array}$ & 200 & 25.5 & 57 & 15 & 2.5 & 0 \\
\hline
\end{tabular}

The descriptive statistics of E-Trust variable shows that $51 \%$ of the respondents agree on the statement of personal data safety and $57 \%$ agree that online stores apply security method.

Table 3 User's Experiences

\begin{tabular}{|c|c|c|c|c|c|c|c|}
\hline \multirow{2}{*}{ Variable } & \multirow{2}{*}{ Statement } & \multirow{2}{*}{$\mathbf{N}$} & \multicolumn{5}{|c|}{ Percentage (\%) } \\
\hline & & & 5 & 4 & 3 & 2 & 1 \\
\hline \multirow[t]{4}{*}{ User's Experiences } & $\begin{array}{l}\text { I hope that the experience of } \\
\text { buying this product has a positive } \\
\text { impact in the future. }\end{array}$ & $\begin{array}{l}20 \\
0\end{array}$ & 35 & 52.5 & 10.5 & 2 & 0 \\
\hline & $\begin{array}{l}\text { I am used to buying Korean } \\
\text { cosmetics brand products in online } \\
\text { stores. }\end{array}$ & $\begin{array}{l}20 \\
0\end{array}$ & 34.5 & 47 & 15.5 & 2.5 & 0.5 \\
\hline & $\begin{array}{l}\text { Since I buy Korean cosmetic brand } \\
\text { products, I will provide insight to } \\
\text { others. }\end{array}$ & $\begin{array}{l}20 \\
0\end{array}$ & 40.5 & 43.5 & 12.5 & 3 & 0.5 \\
\hline & $\begin{array}{l}\text { I see that other customers use } \\
\text { Korean cosmetic brand products }\end{array}$ & $\begin{array}{l}20 \\
0\end{array}$ & 33.5 & 50 & 13.5 & 2.5 & 0.5 \\
\hline
\end{tabular}


The user's experiences of buying Korean cosmetics at online stores tend to be strong; especially on the statement of customers' hope of the products' positive impact (52.5\%), the knowledge that others also use Korean cosmetic brand products(50\%), and the habit of buying Korean cosmetics online (47\%). While very strong agreement is shown on the customers' willingness to provide insight to others (40.5\%)

Table 4. Brand Equity

\begin{tabular}{|c|c|c|c|c|c|c|c|}
\hline \multirow{2}{*}{ Variable } & \multirow{2}{*}{ Statement } & \multirow{2}{*}{$\mathbf{N}$} & \multicolumn{5}{|c|}{ Percentage (\%) } \\
\hline & & & 5 & 4 & 3 & 2 & 1 \\
\hline \multirow[t]{7}{*}{ Brand Equity } & $\begin{array}{l}\text { I realize that these brands are not } \\
\text { local brands. }\end{array}$ & $\begin{array}{l}20 \\
0\end{array}$ & 30 & 49.5 & 18.5 & 2 & 0 \\
\hline & $\begin{array}{l}\text { I feel that the clarity of } \\
\text { information of Korean cosmetics } \\
\text { brands products adds a positive } \\
\text { image. }\end{array}$ & $\begin{array}{l}20 \\
0\end{array}$ & 34 & 45.5 & 17.5 & 3 & 0 \\
\hline & $\begin{array}{l}\text { I feel that the quality of Korean } \\
\text { cosmetics brands products adds a } \\
\text { positive image. }\end{array}$ & $\begin{array}{l}20 \\
0\end{array}$ & 35.5 & 48 & 13.5 & 3 & 0 \\
\hline & $\begin{array}{l}\text { I feel that the uniqueness of } \\
\text { Korean cosmetics brands products } \\
\text { adds a positive image. }\end{array}$ & $\begin{array}{l}20 \\
0\end{array}$ & 44.5 & 36.5 & 17 & 1 & 1 \\
\hline & $\begin{array}{l}\text { I am sure Korean cosmetic brands } \\
\text { have high quality. }\end{array}$ & $\begin{array}{l}20 \\
0\end{array}$ & 41 & 40 & 17.5 & 1 & 0.5 \\
\hline & $\begin{array}{l}\text { I am sure Korean cosmetic brands } \\
\text { are loved by other people. }\end{array}$ & $\begin{array}{l}20 \\
0\end{array}$ & 35.5 & 49 & 14 & 1 & 0.5 \\
\hline & $\begin{array}{l}\text { I faithfully use Korean cosmetics } \\
\text { brands. }\end{array}$ & $\begin{array}{l}20 \\
0\end{array}$ & 35.5 & 49 & 12.5 & 3 & 0 \\
\hline
\end{tabular}

The descriptive statistics of Brand Equity variable has high scores on the realization that the brands are imported (49.5\%), the information is clear (45.5\%) and the quality adds the good image (48\%), so that the customers-as well as the others- will continue using them (49\%). Highest scores are obtained on customers' perception that the brands are unique (44.5\%) and have high quality (41\%).

Table 5. Customer E-Satisfaction

\begin{tabular}{|c|c|c|c|c|c|c|c|c|}
\hline \multirow{2}{*}{\multicolumn{2}{|c|}{ Variable }} & \multirow{2}{*}{ Statement } & \multirow{2}{*}{$\mathbf{N}$} & \multicolumn{5}{|c|}{ Percentage (\%) } \\
\hline & & & & 5 & 4 & 3 & 2 & 1 \\
\hline \multirow[t]{4}{*}{$\begin{array}{l}\text { Customer } \\
\text { Satisfaction }\end{array}$} & E- & $\begin{array}{l}\text { I am satisfied because there are } \\
\text { features that display reviews from } \\
\text { other customers. }\end{array}$ & $\begin{array}{l}20 \\
0\end{array}$ & 31.5 & 53.5 & 12.5 & 2.5 & 0 \\
\hline & & $\begin{array}{l}\text { Thoroughly, I was satisfied with } \\
\text { having the experience of buying } \\
\text { brands of Korean cosmetics from } \\
\text { online stores. }\end{array}$ & $\begin{array}{l}20 \\
0\end{array}$ & 28.5 & 52 & 16.5 & 3 & 0 \\
\hline & & $\begin{array}{l}\text { Completeness information on } \\
\text { Korean cosmetics adds to my } \\
\text { satisfaction value. }\end{array}$ & $\begin{array}{l}20 \\
0\end{array}$ & 33.5 & 50.5 & 13 & 3 & 0 \\
\hline & & $\begin{array}{l}\text { I am satisfied to be treated with } \\
\text { full attention by the online store. }\end{array}$ & $\begin{array}{l}20 \\
0\end{array}$ & 37 & 45.5 & 15 & 2 & 0.5 \\
\hline
\end{tabular}

The scores for Customer E-Satisfaction variable are dominated by strong satisfaction of knowing others' review (53.5\%), the availability of complete information (50.5\%), the full attention given by the online stores (45.5\%) and the overall satisfaction of buying Korean cosmetics online (52\%). 
Table 6. Questionnaire Results on Customer E-Loyalty

\begin{tabular}{|c|c|c|c|c|c|c|c|}
\hline \multirow{2}{*}{ Variable } & \multirow{2}{*}{ Statement } & \multirow{2}{*}{$\mathbf{N}$} & \multicolumn{5}{|c|}{ Percentage (\%) } \\
\hline & & & 5 & 4 & 3 & 2 & 1 \\
\hline \multirow[t]{4}{*}{ Customer E-Loyalty } & I repeatedly bought brands of & & & & & & \\
\hline & $\begin{array}{l}\text { Korean cosmetics at this online } \\
\text { store. }\end{array}$ & $\begin{array}{l}20 \\
0\end{array}$ & 45.5 & 42 & 10.5 & 1.5 & 0.5 \\
\hline & $\begin{array}{l}\text { I will suggest this online store to } \\
\text { others. }\end{array}$ & $\begin{array}{l}20 \\
0\end{array}$ & 45 & 40 & 13 & 1.5 & 0.5 \\
\hline & $\begin{array}{l}\text { I will not switch to any other } \\
\text { online stores that suggested by } \\
\text { others. }\end{array}$ & $\begin{array}{l}20 \\
0\end{array}$ & 45.5 & 43 & 9.5 & 2 & 0 \\
\hline
\end{tabular}

The descriptive statistics of Customers' e-loyalty shows very high scores on all statements; the customers re-purchase the Korean cosmetics brands (45.5\%), are willing to give recommendation to others (45\%), and are not interested to switch (45.5\%).

\section{Analysis}

There are two model tested in this study using Multiple Linear Regression analysis. The first model is used to test hypotheses 1-3 and the second model is used to test hypotheses 4 . The output for the first model can be seen in Table 7 and 8.

Table 7. Multiple Linear Regression Model I Test Results

\begin{tabular}{lllllll}
\hline \multirow{2}{*}{ Model } & & \multicolumn{2}{l}{$\begin{array}{l}\text { Unstandardized } \\
\text { Coefficients }\end{array}$} & \multicolumn{2}{l}{$\begin{array}{l}\text { Standardized } \\
\text { Coefficients }\end{array}$} & \multirow{2}{*}{ Sig. } \\
\cline { 3 - 5 } & & B & Std. Error & Beta & & \\
\hline 1 & (Constant) & 3.365 & .905 & & 3.720 & .000 \\
& TTRU & .087 & .060 & .074 & 1.445 & .150 \\
& TEXP & .530 & .074 & .538 & 7.127 & .000 \\
& TBRE & .130 & .048 & .211 & 2.728 & .007 \\
\hline
\end{tabular}

a. Dependent Variable: TSAT

Table 8. Model Summary I

\begin{tabular}{lllll}
\hline Model & R & R Square & Adjusted R Square & Std. Error of the Estimate \\
\hline 1 & $.735^{\mathrm{a}}$ & .541 & .534 & 1.674 \\
\hline
\end{tabular}

a. Predictors: (Constant), TBRE, TTRU, TEXP

Source: Primary Data (2020)

From the result, it can be seen that E-Trust (TTRU), User's Experiences (TEXP) and Brand Equity (TBRE) have positive relation with Customers' E-Satisfaction (TSAT) with the value of $0.087,0.530$, and 0.130 . The value of $\mathrm{R}^{2}$ is 0.541 which proves that the dependent variable (Customer E-Satisfaction) can be explained by the independent variables (E-Trust, User's Experiences, and Brand Equity) by 54.1\%. While the residual (100 percent -54.1 percent $=45.9$ percent $)$ is explained by other variables outside this study. Meanwhile, the value of $\varepsilon 1$ can be found with the formula $\varepsilon 1=\sqrt{ }(1-0.541)=0.6775$.

Equation 1:

$$
S A T=3.365+0.087 T R U+0.530 E X P+0.130 B R E+0.6775
$$

Thus, this study proves that E-Trust has no influence on Customer E-Satisfaction (H1 is rejected) since the value of significance coefficient of E-Trust is 0.150 (Table 7) which is more than 0.05 . This result contradicts the finding of the research conducted by Soegoto, (2013) which stated that there is a significant relationship between E-Trust and Customer E-Satisfaction. However, the result of this study supports the previous study conducted by Marlien \& Supriyadi, (2015) which states that E-Trust has no influence on Customer E-Satisfaction. H2 and H3 in this study are accepted since the value of significance 
coefficient of User's Experiences is 0.000 which is less than 0.05 , while the value of significance coefficient of Brand Equity is 0.007, which is also less than 0.05 .

Table 9. Multiple Linear Regression Model II Test Results

\begin{tabular}{lllllll}
\hline \multirow{2}{*}{ Model } & & \multicolumn{2}{l}{ Unstandardized Coefficients } & Standardized Coefficients & \multirow{2}{*}{ S } & \\
\cline { 3 - 6 } & & B & Std. Error & Beta & 3.086 & .002 \\
\hline 1 & (Constant) & 2.722 & .882 & & 1.082 & .281 \\
& TTRU & .061 & .057 & .063 & 2.499 & .013 \\
& TEXP & .196 & .079 & .239 & 3.512 & .001 \\
& TBRE & .161 & .046 & .313 & 1.662 & .098 \\
\hline
\end{tabular}

a. Dependent Variable: TLOY

Table 10. Model Summary II

\begin{tabular}{lllll}
\hline Model & R & R Square & Adjusted R Square & Std. Error of the Estimate \\
\hline 1 & $.645^{\text {a }}$ & .415 & .403 & 1.577 \\
\hline
\end{tabular}

a. Predictors: (Constant), TSAT, TTRU, TBRE, TEXP

Source: Primary Data (2020)

Customers' E-Loyalty can be explained by the independent variables including E-Trust (TTRU), User's Experiences (TEXP), and Brand Equity (TBRE), Customers' Satisfaction (TSAT) has positive relations on Customers' E-Loyalty (TLOY) with the value of $0.061,0.196,0.161$ and 0.112 . The value of $\mathrm{R}^{2}$ is 0.415 which shows that the dependent variable can be explained by independent variables by $41.5 \%$. While the residual ( 100 percent -41.5 percent $=58.5$ percent $)$ is explained by other variables outside this study. Meanwhile, for the value of $\varepsilon 2$ can be found with the formula $\varepsilon 2=\sqrt{ }(1-0.415)=0.7649$. Equation 2:

$$
L O Y=2.722+0.061 T R U+0.196 E X P+0.161 B R E+0.112 S A T+0.7649
$$

Customers' E-Satisfaction in this study does not meet the hypothesis which states that it is mediating the influence of E-Trust, User's Experiences, and Brand Equity on Customer E-Loyalty. The value of the direct effect on E-trust through Customer E-Satisfaction is 0.063 and the indirect effect is smaller, that is 0.01 . This result shows that Customer E-Satisfaction has no role on mediating the impact of E-Trust on Customer E-Loyalty. It contradicts with the studies conducted by Soegoto (2013) which stated that Customer's E-Trust has a positive relationship with Customer E-Loyalty through Customer E-Satisfaction.

The value of the direct effect of User's Experiences is 0.239, bigger that the indirect effect value of 0.311. This shows that User's Experiences has a significant, indirect influence on Customer E-Loyalty through Customer E-Satisfaction. This finding is in line with the study result of Verhoef et al., (2009) which stated that there is a significant relationship between User's Experiences and Customer E-Loyalty through Customer E-Satisfaction.

Brand Equity has bigger indirect effect with the value of 0.313 than the direct effect with the value of 0.341. This shows that Brand Equity has indirect influence on Customer E-Loyalty through Customer ESatisfaction. This finding supports the study result of Nam et al., (2011) which stated that there is a significant relationship between Brand Equity and Customer E-Loyalty through Customer E-Satisfaction. Based on the results, hypothesis 4 is not accepted since not all variables have significant, positive result on Customer E-Satisfaction.

\section{Conclussion}

Based on the results and the discussion, the authors conclude that E-Trust does not influence Customer E-Satisfaction, User's Experiences influences Customer E-Satisfaction, Brand Equity influences Customer E-Satisfaction, and Customer E-Satisfaction does not mediate the influence of E-Trust, User's Experiences, and Brand Equity on Customer E-Loyalty.

The questionnaire does not cover all regions in Indonesia, so this study does not represent Gen Z female Indonesian customers. Besides that, the mediating variable does not represent a complete mediation, so it can not represent the E-Trust variable very well. To overcome those limitations, it is 
suggested that the further study takes broader data to create a better representation of the respondents and to strengthen more the theories on mediating variables.

\section{Reference}

Budac. (2014). Strategic Considerations on How Brands Should. Revista Economică, 66(5), 6-14.

Chou, S., Chen, C.-W., \& Lin, J.-Y. (2015). Female online shoppers: examining the mediating roles of esatisfaction and e-trust on e-loyalty development. Internet Research, 25(4).

Debora, Y. (2016). Mendulang Laba dan Kecantikan Wanita. Retrieved July 2, 2019, from https://tirto.id/mendulang-laba-dari-kecantikan-wanita-b9tC.

Deng, Z., Lu, Y., Wei, K. K., \& Zhang, J. (2010). Understanding customer satisfaction and loyalty: An empirical study of mobile instant messages in China. International Journal of Information Management, 30(4), 289-300. https://doi.org/10.1016/i.jiinfomgt.2009.10.001

Eka, D., \& Hamdaini, Y. (2017). Pengaruh Customer Value terhadap Purchase Decision melalui Beauty Blogger di Youtube ( Studi Pada Pelanggan Kosmetik Local Brand di Sumatera Selatan ), 15(4).

Kartajaya, H. (2010). Brand Operation, The Official MIM ( Markplus Institute of Marketing) Academy coursebook. Jakarta: Esensi Erlangga Group.

Katadata.co.id. (2016). Konsumen Indonesia Lebih Suka Merek Kosmetik Global. Retrieved July 2, 2019, from https://databoks.katadata.co.id/datapublish/2016/11/17/konsumen-indonesia-lebih-sukamerek-kosmetik-global

Keller, K. L. (2009). Strategic Brand Management (Building, Measure, And Managing Brand Equity). New Jersey: Prentice Hall.

Lin, C., \& Lekhawipat, W. (2014). Factors affecting online repurchase intention. Industrial Management and Data Systems, 114(4), 597-611. https://doi.org/10.1108/IMDS-10-2013-0432

Lu, L. C., Chang, H. H., \& Yu, S. T. (2013). Online shoppers' perceptions of e-retailers' ethics, cultural orientation, and loyalty: An exploratory study in Taiwan. Internet Research, 23(1), 47-68. https://doi.org/10.1108/10662241311295773

Marlien, \& Supriyadi. (2015). Analisis Kepercayaan, Citra Merek Dan Kualitas Layanan Terhadap Loyalitas Pelanggan Dimediasi Kepuasan Pelanggan (Studi Pada Kreditur Pd. Bkk Dempet Kota Kabupaten Demak), 978-979.

Nam, J., Ekinci, Y., \& Whyatt, G. (2011). Brand equity, brand loyalty and consumer satisfaction. Annals of Tourism Research, 38(3), 1009-1030. https://doi.org/10.1016/j.annals.2011.01.015

Ristanti, V., Shihab, M. S., \& Rekarti, E. (2011). Pengaruh Dimensi Kualitas Pelayanan dan Kepuasan Terhadap Loyalitas Pelanggan. Jurnal Manajemen Dan Bisnis Sriwijaya, Vol.9(17), 1-12.

Shukla, P. (2014). The impact of organizational efforts on consumer concerns in an online context. Information and Management, 51(1), 113-119. https://doi.org/10.1016/j.im.2013.11.003

Soegoto, A. S. (2013). Persepsi Nilai Dan Kepercayaan Terhadap Kepuasan Dan Dampaknya Terhadap Loyalitas Konsumen. Jurnal Riset Ekonomi, Manajemen, Bisnis Dan Akuntansi, 1(3), 1271-1283.

Sugiyono. (2012). Metode Penelitian Kuantitatif Kualitatif dan R\&D. Bandung: Alfabeta.

Tempo.co. (2018). Alasan Wanita Indonesia Lebih Suka Produk Kecantikan asal Korea. Retrieved from https://cantik.tempo.co/read/1159359/alasan-wanita-indonesia-lebih-suka-produk-kecantikanasal-korea. 